\title{
The Noir Landscape of Dublin in Benjamin Black's Quirke Series ${ }^{1}$
}

\author{
Auxiliadora Pérez-Vides \\ Universidad de Huelva, Spain
}

Copyright (c) 2020 by Auxiliadora Pérez-Vides. This text may be archived and redistributed both in electronic form and in hard copy, provided that the author and journal are properly cited and no fee is charged for access.

\begin{abstract}
This article offers an examination of Benjamin Black's Quirke series through an ecocritical lens. Set against the backdrop of 1950s Dublin, the texts feature a pathologist who investigates the murder of the victims that end at the morgue of the Holy Family Hospital. I contend that by exhaustively mapping the city through its crimes, the author hints at the farreaching web of criminal actions executed and sanctioned by different agents of authority and violence. Similarly, I also claim that the author consistently draws on the notions of coexistence and interdependence to construct the personality of the protagonist, as the narrator insists on this growing indignation and cynicism towards the connected artefacts of dominance that inhabit the city. Consequently, the novels suggest that relationality and interdependence should involve untangling that net of power and control so as to negotiate social responsibility and create a climate of greater justice and solidarity.
\end{abstract}

Key words. Ecocriticism, Coexistence, Crime fiction, City landscapes, Dublin Noir.

\section{Resumen.}

Este artículo examina la serie de novelas "Quirke", escrita por Benjamin Black, desde una perspeciva ecocrítica. Las historias, localizadas en el Dublín de los años 50 del siglo pasado, están protagonizadas por un patólogo que investiga los asesinatos de las víctimas que llegan a la morgue del Hospital de la Sagrada Familia. Este artículo pretende demostrar que al rastrear exhaustivamente la ciudad a través de los crímenes que se suceden en ella, el autor sugiere la existencia de una amplia red de acciones criminales ejecutadas y supervisadas por distintos agentes de poder y violencia de la época. También se argumenta que Black utiliza de manera consistente las nociones de coexistencia e interdependencia para construir la personalidad del protagonista, en tanto que el narrador insiste en su creciente indignación y cinismo ante los artefactos de poder que habitan su ciudad. Por todo ello, las novelas sugieren que la relacionalidad y la interdependencia implican también desenmarañar esa red de poder y control, para negociar la responsabilidad social y crear un clima de mayor justicia y solidaridad. 
Palabras clave. Ecocrítica, coexistencia, novela de detectives, paisajes urbanos, Dublín en la novela negra.

\section{Introduction}

In The Ecological Thought (2010), Timothy Morton objects to the traditional association of ecology with purely scientific matters and he defends instead its increasingly evident transversality. Starting from this premise, Morton proposes an alignment of the term with a type of critical thinking about essential concepts like "consciousness", "awareness", "society" and "coexistence", among many others, which conform what he denominates "the ecological thought" (2). For him, relationality should occupy a central position in the current debates about ecology, but always incorporating the wide range of elements of such interactive contact, that is, humans, non-humans, the environment, and the relation among them all. Besides, Morton insists on the necessary practicality of the ecological thought, or what he calls "a new ecological aesthetics: dark ecology", which, he makes clear, "puts hesitation, uncertainty, irony, and thoughtfulness back into ecological thinking" (16). This proposal becomes a useful critical stand for the analysis of the increasingly popular crime fiction genre, as Morton considers noir the most appropriate form of dark ecology. Thus, he calls to mind how "the noir narrator begins investigating a supposedly external situation, from a supposedly neutral point of view, only to discover that she or he is implicated in it" (17). Such formulaic entanglement, along with the genre's underpinning on irony and difference, yield positive results for the ecological critical positioning and also the referential actions that he demands: "With dark ecology, we can explore all kinds of art forms as ecological: not just ones that are about lions and mountains, not just journal writing and sublimity. The ecological thought includes negativity and irony, ugliness and horror ... Ugliness and horror are important, because they compel our compassionate coexistence to go beyond condescending pity" (17).

In a similar vein, in their introduction to a special issue of the journal Green Letters devoted to crime fiction and ecology, Walton and Walton underscore the interrelation between noir texts and ecocriticism by noting not only the growing number of ecocritical connotations in crime narratives, but also how more and more reflections on ecocritical theory and environmental philosophy are informed by detective fiction. Quite accurately, they affirm that writers of the noir genre contribute in significant ways to the cultural perception of issues related to the environment and its current crisis, while also highlighting the analogous function that relevant concepts like agency and responsibility have for these two modes of representation and analysis. Most precisely, Walton and Walton underline the value that the specific formulas that characterise these novels may convey for ecological debates:

The detective, the villain, the crime scene, the locked room, the spree, the red herring, mystery, investigation, false solution, denouement: all these generic features offer opportunities to reflect on the forms and functions of environmental criticism and ecological narratives more generally. If crime fiction is especially fruitful in this regard, perhaps this stems from its curiously strong commitments to both the familiar and to the unfamiliar. (3)

Another referent to grasp the correspondence of crime fiction and ecology becomes evident by the fact that both are closely attached to notions of locality in their grounding orientation. This is the main argument underlying Patrick Murphy's Ecocritical Explorations in Literary and Cultural Studies, where he maintains that ecocriticism should move away from universalism and favour more circumstantial approaches to reality, even when dealing with problems that are global in reach. What he suggests is, then, a reading of literature and popular culture through an ecocritical lens that is "attentive to particular and specific places, entities, and events" (1). 
The same position can be said to sustain most noir texts insofar as, Murphy indicates, crime fiction writers "rely on developing a series of novels built around a single character, or occasionally a team. These characters are usually long-term inhabitants of a particular locale, which facilitates the overlapping of this fiction with literary regionalism" (120). Although the narrative taxonomy of the novels that will be analysed in the present article falls out of its scope, my guiding principle will be very much ascribed to these ideas proposed by Murphy.

In fact, as far as Ireland is concerned this localist view has been endorsed by many critical commentators of the large number of crime novels that have appeared in recent decades on the island. Relevant voices like O'Toole (2009), McDermid (2011), Clark (2014) and Mannion (2016) have argued that local events like the 1990s economic boom of the Celtic Tiger, the Good Friday Agreement and the murder of the crime reporter Veronica Guerin, among others, marked a turning point in the portrayal of Irish crimes within Irish settings. Since then, the many changes occurring on both sides of the border and at different levels have inspired a considerable number of writers of this fictional subgenre, so that quoting Clark, "of all literary forms, it is crime narrative which has most accurately and most successfully mirrored the profusion of transformations which have taken place in Ireland," revealing "the contradictions and incongruities apparent in the new Ireland of the Celtic Tiger and after" (255). On this account, O'Toole declares that Irish crime fiction "has become arguably the nearest thing we have to a realist literature adequate to capturing the nature of contemporary society".

\section{Benjamin Black and the eco-logic of Dublin noir}

In 2006, the Irish writer John Banville published his debut crime novel, Christine Falls, under the pen name Benjamin Black. Since then, the sequels The Silver Swan (2007), Elegy for April (2010), A Death in Summer (2011), Vengeance (2012), Holy Orders (2013), and Even the Dead (2015) have been released to much critical acclaim. ${ }^{2}$ Some of them were also recently adapted for television by the BBC with the general name of Quirke (2016) and starring Gabriel Byrne as the protagonist. The whole series, set against the backdrop of 1950s Dublin, features the middle-aged and loner consultant pathologist at the Holy Family hospital, who is simply known as Quirke. Despite suffering from a troubled past as an orphan educated in an Industrial School and having an intermittent drinking problem, Quirke maintains a privileged but estranged relationship with the artefacts of power in that period, that is, the Catholic Church and the Irish State. With the help of his only loyal friend throughout the series, Detective Inspector Hackett, they both investigate a number of crimes taking place in Ireland's capital city along a decade that has been frequently considered rather stagnant, gloomy and even foreboding (Ferriter).

One of the most distinctive features of the Quirke novels is that they expose the dark corners and submerged operations of mid-twentieth century Irish society, which appears as spinning around twisted practices of power and legitimacy. Particularly evident are the extreme hegemony of the Catholic Church, the ultraconservative social orthodoxy and the air of corruption that permeate the texts, taking a different expression in each of them but equally raising an array of troubling ethical questions. Quoting the author, the 1950s were "a hidebound time" in which people had to show obedience to the Church and their figures of authority:

That was what was so useful for this kind of plots, that it all depends on people being able to keep secrets with great ease, and have that great arrogance, which lasted in Ireland up till the early $1990 \mathrm{~s}$, that says to the people: we don't need to tell you things. You're better off not knowing. We know, we're in control, we're the wise people, the great men. I needed that for the atmosphere of the books. (Jones, emphasis added) 
Actually, in his introduction to Down These Mean Streets: Irish Crime Writing in the TwentyFirst Century, Ian Campbell Ross celebrates Black's use of such historical retrospection for what can be further read as a critique of the current state of affairs on the island, as previously done by novelists like Edna O'Brien or John McGahern from other fictional subgenres. Most acutely, Ross points out the author's close attention to minutiae when he observes how Quirke "anatomises the Ireland of the 1950s as he does its victims" (33), which in itself constitutes a fine metaphor of the correlation between the pathological component of the corpses that the pathologist must examine and the evil character of the ideological apparatus that is ultimately responsible for their death.

Taken together, the Quirke novels touch on a number of crimes that stemmed from that milieu, like illegal adoption (Christine Falls and Even the Dead), sexual exploitation and drug dealing (The Silver Swan), incest and backstreet abortion (Elegy for April), paedophilia (A Death in Summer) and clerical abuse of young children (Holy Orders). Their impact rests not only on the narrative articulation of atrocities that had been absent from public discourse for a long time, but also on raising awareness about the ongoing effects of such ethos of dominance upon the Irish collective psyche, as the novels also suggest that accountability has not been sufficiently tackled in the present. Not surprisingly, the publication of the Quirke series runs parallel with the wave of academic studies, survivor memoirs and artistic productions that have made public some of the hidden intricacies of that era in the island, demanding at the same time, justice and redress for the victims. By and large, a substantial body of texts have displayed, for example, the terror regime and sexual abuse within Catholic-run institutions - like Industrial Schools or Magdalene Laundries - and the complicity of the State and the wider society in perpetuating this tyrannical treatment of "deviant" individuals, which have strongly agitated sensibilities in Ireland and worldwide (Raftery and O'Sullivan 1999; Smith 2007; O'Sullivan and O'Donnell 2007).

Although Banville, or hereafter Black, has repeatedly denied a deliberate social aim when he conceived his Quirke series, claiming that the Church related scandals are simply part of the Irish history "material" that any writer can play with (Inskeep), there are compelling reasons to understand his choice of the crime fiction genre as an unequivocal account of the many tensions and paradoxes that prevailed in Ireland from the 1950s onwards. David Clark, one of the leading scholars in the analysis of the literary phenomenon known as "Emerald Noir", has insisted on the progressive significance of this genre, claiming that 'the essentially 'realist' infrastructure of most crime fiction gives it a particular clear mandate to fulfil the early Marxist criteria for social fiction, providing, as it were, an accurate picture of society and its inherent contradictions" (145). In the same vein, in Irish Crime Fiction Brian Cliff observes that the novels of this genre produced recently in Ireland reflect the specificity of the country. In his own words, "serial-killing levels of violence do take place within effective Irish national narratives, but that violence is ascribed less to an individual sociopath and more to pathological institutions, which in turn reflect wider pathologies of the society in whose name they act" (12).

Following these and other similar approaches to noir narratives, my reading of Black's Quirke series is informed by the belief that by choosing this particular literary subgenre and providing a retrospective insight into mid-twentieth century Ireland the author creates a distinctive imaginary where uneasy issues of the contemporary Irish milieu and the secreted dealings of its ruling class can be unearthed and contested. To this aim, and with an unchanged aesthetics throughout the different novels, Black thoroughly depicts the sordid atmosphere and bleak social landscape of that particular zeitgeist which, he claims, is the ideal location for this type of books: "If you are going to write crime fiction ... Dublin in the '50s is absolutely perfect - all that poverty, all those secrets, all that fog, all that cigarette smoke, all those drink fumes perfect noir territory" (Inskeep). Actually, Black's production has often been called 
"atmospheric" and praised for describing Dublin "in loving detail" (Phillips 173), a technique that recurs in all the books in the series and with the same intensity.

Taking all these ideas into consideration, in this article I argue that the recurrent emphasis on scenery and topography in the Quirke series does not simply respond to the imperative contextualization of the stories, but it suggests an allegorical construct of the intricate system of power that pervaded the country in the 1950s and which, in many respects, continues in operation in the present. Particularly, it is my contention that by exhaustively mapping the city through its crimes and alluding to their inter-relationality, the author hints at the far-reaching web of criminal actions that have been executed and sanctioned by different agents of authority and violence. In addition to that, I claim that the portrayal of such atmosphere of transgressions and corruption correlates with the configuration of the main character, since the author consistently draws on the notions of coexistence and interdependence whereby Quirke, the othered and misanthropic crime fiction investigator, gradually shows a complex material relatedness with his immediate surroundings. All these elements allow for an ecocritical interpretation of the series, as the meticulous description of Quirke's moves all over Dublin during his processes of detection not only offers a detailed tour of the city, but it also suggests the intersection of the physical and social environment, given the narrator's insistence on his growing indignation and cynicism towards the connected artefacts of dominance that inhabit the city. In order to examine these narrative articulations, I will first describe how the notion of urban interconnection is construed, and then consider Black's handling of place and nature-related tropes and their import in Quirke's development as a character.

\section{Crime and interconnection in Dublin}

Black's setting of the Quirke series in Dublin city responds to one of the most common formulas in crime fiction by which the metropolis, traditionally a locus of connection and interdependence, is described as offering multiple occasions of sin and criminal behaviour. In Kincaid's words, "noir sees the city as a problem, the source of pleasure and vice, a space that needs to be charted and understood" (42). Quite notably, in Black's novels, Dublin is clearly the site of central government and power, and the place where the ruling class's indifference to social discomfort can be most immediately grasped, whereas at the same time, in its urban scenarios any attempt to question hegemony or counteract this overrule is met with further victimization. As O'Cuilleanáin puts it, "etymologically, 'capital' reminds us that the cities are the head of the body politic, placed above the other cities of the state, even speaking for the nation in its entirety. Usually centers of state governance and authority, capital cities may encourage us to draw semantic parallels with the term 'capital punishment'" (1-2).

From Christine Falls to Even the Dead, Black's narrator becomes a cartographer of a city that is mapped out over the course of the investigations of the criminal pathologist and his allies, like Detective Hackett or more evidently as the series progress, Quirke's daughter, Phoebe. In a clearly Joycean mode, ${ }^{3}$ the reader travels throughout Dublin and stops in locations like Grafton Street, Adelaide Road, Pearse Street, College Green, Sandycove, Rathgar, Phoenix Park or Stoneybatter, among many others, although the main hub is actually the Merrion Square and Herbert Park area near the protagonist's apartment in Upper Mount Street. According to one of the reviewers of the series, "Banville's strengths not only lie in his unforgettable backdrops but in his ability to lull the reader into a false sense of security with his descriptions of the mundane - and then delivering an unexpectedly graceful ballet of cruelty that shocks even though it appears inevitable" (Ames). Thus, this broad spectrum of places and the noir elements that the author inscribes in them quite graphically, like dim light, murder, ghostly figures, corruption, blackmailing or attacks in dark alleys, function as a recognisable contextual 
framework that also brings to mind the ideas of familiarity discussed by Walton and Walton and mentioned above. In this sense, the author can be said to play with the reader's spatial identification by suggesting, on the contrary, how the details of such proximate ethos may have been concealed, broadly unknown and/or ignored by the inhabitants of the city and the wider Irish society.

Therefore, Black's Dublin emerges as the place where the Irish ruling class resides and where their dubious dealings can be most readily carried out, but also secreted. The effects of this synecdochical construction of the city are masterfully described in Elegy for April, where Quirke and Hackett investigate the disappearance of a young woman, April Latimer. The fact that she comes from an affluent and influential family of doctors that are regular guests of Archbishop McQuaid and also relatives of the Minister of Health puts Quirke off at the beginning of the case, whose detection eventually exposes practices of incest, abortion and murder. After he admits to Hackett that he does not like this kind of people, the narrator indicates that it is because for the pathologist in Dublin "power is like oxygen, being similarly vital, everywhere pervasive, wholly intangible; he lived in its atmosphere but rarely realized he was breathing it" (Black, Elegy 70). Embedded in what constitutes, to my mind, one of the finest nature-related metaphors in the whole series is the critique to the extensive reach of the agents of control and dominance in the 1950s, which functioned on both the horizontal and the vertical levels of society.

Gradually, Quirke becomes more and more appalled by the fractures that this system of control provokes in the Irish social climate, which for him radiate deceit and hypocrisy: "However tranquil the scene before us, beneath our feet another world is thrashing in helpless agony. How can we live up here, knowing what goes on down there? How can we know and not know, at the same time? He would never understand it" (Black, Even 216). This reflection attests to what Scaggs has observed about the mystery genre when he claims that "the fakery and artifice that characterise the modern city of hard-boiled fiction drive a wedge between what is seen and what is known, and in this way the private eye's quest to restore order becomes a quest to make sense of a fragmented, disjointed, and largely unintelligible world by understanding its connections, or, more often, its lack of connections" (72).

The enormous pull exercised by the agents of power can also be understood through a number of natural images that recur in the crime story of Christine Falls, which is later revisited by Black in Even the Dead. Both novels tackle the illegal trafficking of babies from Ireland's Magdalene Laundries and Mother and Baby Homes to rich American families that was managed by several religious orders, and sanctioned by the Catholic lay community on both sides of the Atlantic. In the first title, the pathologist unravels the mysterious death of the eponymous woman, who had died while giving birth to the child of his own adoptive father, Gareth Griffin, a famed and highly respected judge and also a leading figure of a Catholic organisation known as "The Knights of St. Patrick". Christine's death records had been manipulated by Malachy Griffin, Quirke's brother and a renowned obstetrician who also works at the Holy Family Hospital, in an attempt to cover the judge's extramarital affair with the young woman. Also relevant in the case is Dolly Moran, the matron who attended the concealed childbirth but who is later murdered after threatening the judge and his thugs with revealing the details of Christine's pregnancy and of the selling of the baby to a family in Boston. The whole set of events, replete with double standards, secrecy and criminal actions, were for Quirke "a wide and tangled web in which he had become enmeshed" (Black, Christine 253). Again, the author's insistence on the interconnected network of power may be interpreted through the notions of coexistence and relationality suggested by Morton, although they are certainly at this point associated with the negative effects brought about on both the victims, like the dead women, and those who try to achieve reparative justice, like Quirke. 
Actually, in his attempt to restore order and denounce the dealings of the Knights of St Patrick, the pathologist is warned by Detective Hackett that "There'll be a lot of dust ... if these particular pillars of society are brought down. A lot of dust, and bricks, and rubble. A body would want to be standing well out of the way" (Black, Christine 390). Yet, as the conventional crime fiction hero, Quirke ignores this recommendation and continues with his disclosure of systemic corruption and wrongdoing in the subsequent titles in the series. What he finds, though, is a circle of power whose impenetrability is epitomised by the many obstacles he must face while visiting a Magdalene laundry in order to further examine the illegal network of adoption of babies born to single mothers and other interns of these institutions. His frustration and pessimism are voiced when he admits to Phoebe: "Places like that laundry are protected. There's an invisible fence around them that you won't break through. Take my word for it. I tried and I failed. Inspector Hackett failed. That's the way it is" (Black, Even 195). Also worthy of note is the hyperbolic and animalistic image used to refer to the collusion of Church and State and the extent of their control, influence and violence that is voiced in one of Quirke's ethical ruminations at the end of Even the Dead: "Could he have done more? Should he have persevered? Should he have carried that fight into the belly of the beast itself? Pathetic notion. The beast would have belched him out and turned its back and slouched off about its beastly business" (215).

\section{Urban setting and the characterisation of Quirke}

The noir generic convention of presenting a protagonist-hero who experiences an epistemological quest ${ }^{4}$ while consistently being puzzled by the ills of his/her immediate social habitat can be clearly traced through Black's articulation of the plots and his process of characterisation of Quirke throughout the series. Besides, this narrative constituent of the crime novels renders another possibility for the interpretation of the novels from an ecocritical approach, which can be substantiated through Walton and Walton when they remark that:

Within ecocriticism, the figure of the detective is richly suggestive. Whether as a singular or collective agency, the detective has been constructed as a figure capable of perceiving systematicity and apprehending totality. Emerging from the crowded conditions of the nineteenth century metropolis, canonical figures like Auguste Dupin and Sherlock Holmes perform an epistemological function: transforming the chaotic multiplicity of the city into a series of links in a chain, leading back to a verifiable 'truth'. But in the face of their overwhelming responsibilities, the detective figure has often become distributed, collective, cyborg, even liquid. (2, emphasis added)

The words "systematicity" and "liquid" have been emphasized in the quoted paragraph for two main reasons. One the one hand, it has been discussed in the third section of this article how Quirke's perceptions and concerns become the narrative archives whereby the author displays and criticises the infrastructure of power of 1950s Dublin. On the other hand, the tormented and impressionable, yet cynical and contemptuous, personality of the protagonist allows Black to construct the composite nature as well as the shifting social attitude of the pathologist.

The terms of such idiosyncratic fluidity are predicated on the increasingly prominent role that space and ambiance acquire in the development of his character. Obviously, this starts with Carricklea, the fictional name given to the Industrial School in which Quirke spent his childhood before being adopted by the judge, who is finally revealed to be in fact his biological father. The enormous pull exercised by this institution upon Quirke's emotional and mental state can be grasped at different moments in the series, although it is certainly summarised when in Christine Falls he declares to Phoebe that Carricklea is "the kind of place that stays with 
you" (Black, Christine 78). Quite frequently, particular noises, smells and images bring him mentally back to the school where he was mistreated and sexually molested, attesting to the grip and effect this place has on his psychological and emotional state, being extraordinarily apparent in Holy Orders. In addition to this, particular attention must be given to the morgue of the Holy Family Hospital, which more than a conventional spot in crime thrillers is described as standing for Quirke as a microcosm of society, a place where its own criminal workings can be disentangled. There the pathologist performs his post-mortems on corpses every day, but it is also the space where he meditates about existential and ethical issues, like the coextensivity of life and death, the degeneration of the perpetrators of the murders and, most importantly, his own professional and moral function in determining the causes of death. Along the series, Quirke's reflections at the morgue and over the corpses convey, for example, the scapegoating practices suffered by the victims of Ireland's social depravity. This interpretation of the dead bodies as targets of wider anxieties of cultural disintegration permeates the series, but it is in Christine Falls where the terms of such embodiment and its impact upon Quirke are most clearly presented to the reader:

It sometimes seemed to Quirke that he favoured dead bodies over living ones. Yes, he harboured a sort of admiration for cadavers, these wax-skinned, soft, suddenly ceased machines. He suspected, too, that he was becoming more and more like them... He would stare at his hands and they would seem to have the same texture, inert, malleable, porous, as the corpses that he worked on, as if something of their substance were seeping into him by slow but steady degrees. Yes, he was fascinated by the mute mysteriousness of the dead. Each corpse carried its unique secret - the precise cause of death - a secret that it was his task to uncover. For him, the spark of death was fully as vital as the spark of life. (64)

Apart from its evident noirish effect, this passage is worth consideration for implying that corpses are natural portions of matter saturated with the outer manipulation performed upon the victims' bodies, while also illustrating the material interrelatedness and the fluid nature of the pathologist commented above. It is probably for this reason that throughout the series considerable narrative space is given to detailed descriptions of how Quirke dissects the corpses, for which Black has admitted having received the guidance and inspiration from a pathologist friend of his (Jones). In so doing, the author may be following generic codifications but it can also be interpreted as an echo of the human-nature-human encounters brought into notice in previous sections of this article.

Similarly, a great deal of the contextualisation of the stories and Quirke's characterisation is focused on his visits to pubs, hotels and dining halls, like McGonagle's, Toners, The Shelbourne and The Gresham, all very popular spots to drink and socialise in Dublin in the 1950s. This can be explained as a device to characterise him as an alcoholic, although it seems quite plausible that these locations certainly are projections of the sociospatial dimension of the infrastructure of power that governs the city, and whose main perpetrators inhabit this type of places. In addition to this, it appears as another referent of the effects that space and ambiance provoke upon the protagonist's mood. In Holy Orders the action brings us to Flynne's Hotel, where Quirke meets a priest involved in the obscure death of a reporter who was investigating sexual abuses within a tinker community. The description of the place, where Judge Griffin used to bring Quirke when he was young in what were for him endless hours of gossip about courts, laws, criminals and Catholic societies, captures magnificently the multiple sensations that the pub's environment provokes upon the pathologist: 
It was not the threadbare carpets or the greasy armchairs or even the pervasive smell of boiled cabbage that he most objected to. The place was a throwback, shoddily preserved from an older, harsher time ... He found bars like this dispiriting and yet mutedly exciting too, despite himself. They were, he supposed, the kind of shabby-genteel places, dimly lit, forlorn and slightly sinister, where he felt most at home. (Black, Holy 145)

Again, the interior atmosphere of the hotel bar triggers Quirke's empirical observation of sorts, and it becomes a further element to understand his attachment to ambiance, as well as his judicious note about the social lethargy and stagnation of the city. However, the narrator's comments also bring in the notion of security, which is another central issue in the urban landscape of Dublin highlighted by Black in the series, and that preoccupies Quirke at large. Cormac O'Cuilleanáin claims that in the metropolis, "interconnections can be threatening as well as sustaining ... We huddle together for safety, we need institutions to keep our enemies at bay and yet we cannot know and trust every fellow citizen, and the concentration of our needs and aspirations renders us more vulnerable than if we were strung out defencelessly across the countryside" (49). This dialectics is particularly discernible in the pathologist, whose dislocation on a number of levels is apparent in all the novels, but he maintains a constant, though paradoxical, relation with his close environs. In Even the Dead Quirke admits to considering Dublin "a mean and mendacious little city" (73), an aversion that had taken different forms in the previous texts. Thus, after being beaten by a group of thugs as a warning to stop his enquiries about the dealings of the Knights of St Patrick, he is said to feel "a kind of dawning alarm, as if the smooth, empty little island on which he had been happily perched had given a preliminary heave, and would presently reveal itself to be not dry land at all but the humped back of a whale" (Black, Christine 168). An equally striking reference to this threatening background and constructed in animalistic terms can be found in the latest title, where the narrator indicates how a flock of seagulls evoke for Quirke the watchful and secretive nature of the city that he certainly abhors: "Gulls were wheeling above the river, ghost-like in the twilit air. Why, Quirke wondered, do they go silent as night approaches? Making no sound, they seem even more eerie. 'I've just realized something. I'm tired of this country, of its secrets and its lies"' (Black, Even 218).

Nevertheless, Quirke also embodies the complex, double-sided bond with the city pointed out by O'Cuilleanáin in his discussion of the notions of security and vulnerability, as represented in the noir discourse of urban scenarios. The terms of such ambivalence are described in Holy Orders, which is the title in the series where scenery becomes a most distinct mechanism for Quirke's characterisation, particularly in relation to other major characters, like Hackett or Phoebe. A polarised reaction to landscape and natural elements can be grasped, on the one hand, through the novel's insistence on the close contact with animals and the environment that characterise the tinkers' way of life, in clear contrast with the less bucolic constituent of urban existence. Thus, when the protagonist finds himself in the middle of a camping site in Tallaght for the investigation of a reporter's murder, we learn that being in one of the farthest suburbs from Dublin city centre seems for him like "arriving at a village in the deep heart of the country", and he feels intimidated by "the picturesqueness" of the area (Black, Holy 215). On the other hand, along the story the dichotomies Quirke/Hackett and Quirke/Phoebe become more and more apparent, and their divergence is regularly articulated through their different feelings and attitudes towards their natural surroundings. In this vein, whereas Phoebe tends to abhor the stuffy atmosphere of bars and hotel salons preferring the open air of Dublin parks and its lively streets, and Hackett envies the tinkers for living "out in the good air, under God's clear sky" (Black, Holy, 217), Quirke is always unenthusiastic about these locations because of the negative effects that they have upon his mood and temper. 
Actually, during their short stay in Tallaght his immediate suffocation illustrates an aversion to rurality, but it also ushers in a tangled relation to the metropolis: "Being in the open like this, exposed in the midst of so much countryside, made him feel uneasy: he was a city man, and preferred his horizons bounded" (Black, Holy 215). Embedded in this final declaration we can find the contradictory urban experience that he has developed, which attests, again, to his fluidity and also his dislocation. In addition to this, with these final comments about the protagonist's state of mind, the author suggests, though, that the only definite conclusion to be reached in this respect is that Quirke is never comfortable anywhere, and that he is, ironically, another victim of the pandemic power that permeates the city.

\section{Conclusion}

Reading the Quirke series from an ecocritical approach allows me, then, to conclude that the noir landscape of Dublin constructed by Black in the novels demonstrates the inner and outer reach of the notions of space and environment, as they become essential elements for his literary rendering of systemic crime in Ireland's capital city. Thus, the contextual references and ambiance-related imagery that pervade the texts should not be dismissed as codified narrative strategies within the crime fictional frame in which the stories are conceived and articulated. On the contrary, they symbolise the extensive grip that power mechanisms have for the most abject individuals of society, whose process of victimisation is unravelled by Quirke. As this article has tried to prove, by drawing on nature for his charting of the urban web of multiple forms of corruption, the author shapes the interconnection of the state apparatuses for their biased interpretations of social norms, morality, and justice. Similarly, Black's construction of the pathologist-hero endorses the current ecocritical postulates about the relationality of the individual with his/her immediate physical environment, insofar as Quirke's existence is strongly affected by both the material underworld of Dublin and the symbolic trap in which he dwells along the series, and whose persisting hold is hard, or certainly impossible, for him to break. While this familiar unfeasibility of the restoration of social order on the part of the noir protagonist offers another look to the collusion of Church and state in the 1950s, it ultimately encapsulates Black's demands for extratextual and transhistorical action. Relationality and interdependence, he seems to suggest, should involve untangling the net of power and control whose dynamics continues in operation in the present, so as to negotiate social responsibility and create a climate of greater justice and solidarity.

\section{Notes}

${ }^{1}$ The author wishes to acknowledge the funding provided by the Spanish Ministry of Science, Innovation and Universities (Research Project "Bodies in Transit 2", ref. FFI2017-84555-C2-1-P), the European Regional Development Fund, the Spanish Research Agency and the Regional Ministry of Economy, Knowledge, Enterprise and Universities of Andalusia (Project "Embodiments, Genders and Difference: Cultural Practices of Violence and Discrimination," ref. 1252965) for the writing of this essay.

${ }^{2}$ Black's novels have received widespread attention in Spain. Shortly after their release in English, all the titles in the Quirke series were translated into Spanish and published by one of the leading editorial presses in the country, Alfaguara. His growing popularity in Spain can also be evidenced by the fact that Pecado (2017), set in 1950s Ireland and introducing the new detective St. John Strafford, was first published in Spanish and Catalan, also winning the RBA Crime Novel Award.

${ }^{3}$ For a comparison between the Quirke series and Joyce's critique of Irish social inertia as voiced through Leopold Bloom in Ulysses, see McNamara.

${ }^{4}$ According to Neil Murphy, it is precisely this emphasis on the consciousness of the protagonist what links Black and Banville's works, as examined in Chapter 6 of his study John Banville (2018, 159-186). 


\section{Works Cited}

Ames, Heather. "Christine Falls". Blogcritics. 2006.

Black, Benjamin. Christine Falls. London: Picador, 2006.

. The Silver Swan. London: Picador, 2007.

Elegy for April. London: Picador, 2010.

A Death in Summer. London: Mantle, 2011.

Vengeance. London: Mantle, 2012.

Holy Orders. London: Mantle, 2013.

Even the Dead. New York: Henry Holt, 2015.

Pecado. Barcelona: RBA, 2017.

Clark, David. "Emerald Noir?: Contemporary Irish Crime Fiction". East Meets West. Ed. Reiko Aiura, J.U. Jacobs and J. Derrick McClure. Newcastle upon Tyne: Cambridge Scholars Publishing, 2014. 144-156.

Cliff, Brian. Irish Crime Fiction. London: Palgrave, 2018.

Ferriter, Diarmaid. Occasions of Sin: Sex and Society in Modern Ireland. London: Profile, 2009. Inskeep, Steve. "Sleuthing around Dublin's Dark Corners". National Public Radio. 2 September 2011. http://www.npr.org/2011/09/02/139922975/sleuthing-arounddublins-darkest-corners

Jones, Malcom. "Crime Novelists Compare Notes on Seedy Fiction”. Newsweek. 22 April 2007. https://www.newsweek.com/crime-novelists-compare-notes-seedy-fiction-97783

Kincaid, Andrew. "Down These Mean Streets: The City and Critique in Contemporary Irish Noir". Eire-Ireland 45. 1 and 2 (2010): 39-55.

Mannion, Elizabeth. The Contemporary Irish Detective Novel. London: Palgrave, 2016.

McDermid, Val. "Emerald Noir: The Rise of Irish Crime Fiction". BBC Radio Four. 8 March 2011. http://www.bbc.co.uk/programmes/b00z5c85

McNamara, Audrey. "Quirke, the 1950s, and Leopold Bloom". The Contemporary Irish Detective Novel. Ed. Elizabeth Mannion. London: Palgrave, 2016. 135-148.

Morton, Timothy. The Ecological Thought. Cambridge, Mass: Harvard University Press, 2010.

Murphy, Patrick. D. Ecocritical Explorations in Literary and Cultural Studies: Fences, Boundaries, and Fields. Plymouth, UK: Lexington Books, 2009.

O'Cuilleanáin, Cormac. "Crimes and Contradictions: the Fictional City of Dublin". European Crime Fictions: Crime Fiction in the City. Ed. Lucy Andrew and Catherine Phelps. Cardiff: University of Wales Press, 2013. 47-64.

O'Sullivan, Eoin and Ian O'Donnell. "Coercive Confinement in the Republic of Ireland: The Waning of a Culture of Control". Punishment and Society 9. 1 (2007): 27-48.

O'Toole, Fintan. 2009. "From Chandler and the 'Playboy' to the Contemporary Crime Wave". The Irish Times. 21 November 2009. https://www.irishtimes.com/culture/tv-radioweb/from-chandler-and-the-playboy-to-the-contemporary-crime-wave-1.776393

Raftery, Mary and Eoin O'Sullivan. Suffer the Little Children: The Inside Story of Ireland's Industrial Schools. Dublin: New Island, 1999.

Ross, Ian Campbell. "Introduction". Down These Green Streets: Irish Crime Writing in the Twenty-First Century. Ed. Declan Burke. Dublin: Liberties Press, 2011. 16-37.

Scaggs, John. Crime Fiction. London and New York: Routledge, 2005.

Smith, James. Ireland's Magdalene Laundries and the Nation's Architecture of Containment. Manchester: Manchester University Press, 2007.

Walton, Jo Lindsay and Samantha Walton. "Introduction". Green Letters: Studies in Ecocriticism 22. 1 (2018): 2-6. 
Received: 30 January 2020 Revised version accepted: 17 August 2020

Auxiliadora Pérez-Vides is Senior Lecturer in English at the University of Huelva, Spain. She has conducted extensive research on the intersection of gender, nation, family and social history in contemporary Ireland as well as on the representation of single maternity in Irish fiction, cinema and art. Her publications include Sólo ellas: familia y feminismo en la novela irlandesa contemporánea (2003) and the co-edition of Espacios de Género (2005), Single Motherhood in Twentieth Century Ireland: Cultural, Historical and Social Essays (2006), Gendering Citizenship and Globalization (2011), Experiencing Gender: International Approaches (2015) and Words of Crisis/ Crisis of Words: Ireland and the Representation of Critical Times (2016). She has also published on motherhood and women's corporeality, concentrating on the work of Catherine Dunne, Mary Rose Callaghan, Edna O'Brien and Mary Leland, among other authors. Her current research interests focus on the repression of the institutionalised body, the cultural manifestations of Ireland's Magdalene Laundries and the social dimension of John Banville's crime fiction as Benjamin Black. She is a member of the Research Project "Bodies in Transit 2: Genders, Mobilities, Interdependencies", funded by the Spanish Ministry of Science, Innovation and Universities.

mariaa.perez@dfing.uhu.es 